Bangladesh J. Sci. Ind. Res. 42(1), 53-58, 2007

\title{
Studies on the Relation Between Water Activity and Sensory Qualities as well as Chemical Changes of Coriander (Coriandrun sativum) Powder in Flexible Packaging Films
}

\author{
M. M. Rahman, G. Kibria, Z. H. Bhuiyan, K. Chowdhury, S. Khan and R. Karim \\ Institute of Food Science \& Technology (IFST), BCSIR, Dhaka-1205
}

\begin{abstract}
Selection of suitable packaging film is necessary to minimize the deteriorative changes of foods. Packaging films differ for different food products. Flexible packaging films are now widely used instead of hard packages for processed dry food products. In this study attempt has been made to select a suitable packaging film for dry coriander powder at ambient temperature. Three types of packaging films like heat sealable laminated aluminium foil, high density polythene (HDPE) and poly propylene (PP) were chosen. The changes in water activity, total ash, acid insoluble ash and consequent effect on sensory qualities like texture, colour, flavour and appearance of coriander powder were investigated at an interval of two months during one year storage period.
\end{abstract}

\section{Introduction}

Spices are plant products and are used in coriandrol, an isomer of geraniol food to improve flavour, colour and taste. (Swaminathan) and is identical with $d$ The main constituents are carbohydrates, linalool (b.p.194-198 ${ }^{\circ} \mathrm{C}$ ) (Wealth of India, volatile oil, fixed oils, proteins, tannins, 1950). The experiment was carried out in the resins, pigments and mineral etc. In this Institute of Food Science and Technology, study coriander powder was chosen. Locally BCSIR, Dhaka. it is known as dhane or dhania. Botanically it is known as coriandrum sativum (Ahmed, 1984). The stem, leaves and fruits have a pleasant aromatic flavour and is used in preparing chutneys, sauces and soups. The leaves constitute a rich source of vitamin C (250 mg/100 g) and of carotene (5200 $\mu \mathrm{g} / 100$ g) (Basu, et. al., 1974). The aromatic flavour and taste of coriander fruit is due to an essential oil in it. The chief constituent of the oil is

\section{Materials and Methods}

Raw materials

Five kilogram (5 kg) of local variety dry coriander seed was collected from local market of Dhaka city. Care was taken to collect the samples without any infection, damage and injury on the body. The average diameter is $1.2 \mathrm{~cm}$ (max.1.5 cm and min. $0.9 \mathrm{~cm}$ ). 
Hundred gram coriander seed contains about 8475 seeds. The coriander seeds were then washed in cold water to remove adhered dust and debris. These were sun dried for consecutive three days. The weight loss was found to be $10.0 \%$. The coriander seeds were then powdered in a mill, the milling loss was $3.3 \%$. The powdered coriander was sieved with 40 mesh sieve. The sieving loss was found as $2.3 \%$. The final weight of coriander powder for this study was found $4.25 \mathrm{~kg}$. No preservative was added with the coriander powder. Although the post harvest history is unknown but the coriander powder fulfills the requirements of Bangladesh Standards and Testing Institution (BSTI) (Bangladesh Standard, 1984).

\section{Packaging materials}

Three types of flexible packaging films were chosen for this study viz. heat sealable laminated aluminium film (thickness, 132 microns), high density polyethylene (HDPE) film (thickness, 50 microns) and polypropylene (PP) film (thickness, 35 microns). None of the packaging materials were printed. through a piece of film having unit area, in unit time with unit differential across the faces (Ranganna, 1991).

\section{Methods}

Water activity was determined by water activity Meter, Novasina. The thickness of packaging films were measured by thickness gauze. Water vapour transmission rate was measured by WVTR measuring equipment. The rough weight of the samples were taken in a scale. Fine weights were taken in digital electronic balance. Ash was determined using Muffle furnace at $600^{\circ} \mathrm{C}$ for 6 hours heating followed by weighing in electronic balance. Acid insoluble ash was determined by weighing in an electronic balance followed by washing the ash in dilute $\mathrm{HCl}$ and then drying in oven for constant weight (AOAC 2000). The moisture content was determined by using electronic moisture meter.

For this study, the coriander powder was divided into three samples. Sample-A was used for packaging studies using heat seal

Table I. Water vapour transmission rate (WVTR) and thickness of different packaging films

\begin{tabular}{l|c|c}
\hline Name of the flexible packaging films & WVTR (g/sq.m/day) & Thickness ( (microns) \\
\hline Heat sealable laminated aluminium film & 0.03 & 132 \\
High density polyethylene (HDPE) & 20.0 & 50 \\
Poly proylene (PP) & 20.0 & 35 \\
\hline
\end{tabular}

The permeability of a film (gas or water vapour transmission of the film) is defined as the quantity of gas (or water vapour) passing able aluminium film, Sample-B for high density polyethylene (HDPE) film and the Sample-C for polypropylene (PP) film. 


\section{Sample-A}

About 50-60 g coriander powder was filled into each of 10 heat sealable aluminium film bags (thickness 132 microns) and sealed airtight by a thermal sealing machine. Eight sealed coriander powder bags were stored in ambient condition (room temp.). One bag was stored in humidity chamber (temp. $38^{\circ} \mathrm{C}$ and humidity 85-90 \%) for 15 days. The reference sample was stored at low temperature $\left(+5^{\mathrm{O}} \mathrm{C}\right.$, in a refrigerator) for one year. Perforated steel almirah was used for conducting storage studies.

\section{Sample-B}

About 50-60 g coriander powder was filled into each of 10 HDPE film bags (thickness 50 microns) and sealed airtight by a thermal sealing machine. Eight sealed coriander powder bags were stored in ambient condition (room temp.). One bag was stored in humidity chamber (temp. $38^{\circ} \mathrm{C}$ and humidity 85 $90 \%$ ) for 15 days. The reference sample was stored at low temperature $\left(+5^{\circ} \mathrm{C}\right.$, in a refrigerator) for one year. Perforated steel almirah was used for conducting storage studies.

\section{Sample-C}

About 50-60 g coriander powder was filled into each of 10 Polypropylene (PP) film bags (thickness 35 microns) and sealed airtight by a thermal sealing machine. Eight sealed coriander powder bags were stored in ambient condition (room temp). One bag was stored in humidity chamber (temp. $38^{\circ} \mathrm{C}$ and humidity 85-90\%) for 15 days. The refer- ence sample was stored at low temperature $\left(+5^{\mathrm{O}} \mathrm{C}\right.$, in a refrigerator) for one year. Perforated steel almirah was used for conducting storage studies.

\section{Results and Discussion}

After two months interval each bag of coriander powder was analysed for water activity, moisture content (weight loss or gain), total ash and acid insoluble ash. Water activity has come to be widely accepted (Gilbert,1986) as the effective concentration of water in a substance which controls its susceptibility to the biological and chemical spoilage (Gilbert, 1986). The appearance, colour, flavour and texture were determined by sensory evaluation.

It is observed from Table II that the water activity is almost same in heat sealable laminated aluminium film throughout the storage period but increased in case of HDPE and PP film. From Table III it is observed that initial weight of coriander powder remained almost same in heat sealable laminated aluminium film but increased during storage period in other two packaging materials. Similar observation has also been found for moisture content except in few observations. It is due to the absorption of moisture by the sample during storage period. Changes in ash and acid insoluble ash are shown in Table IV which is also consistent with the increased weight.

Table V, VI and VII show the sensory qualities like texture, colour, flavour and appearance of the coriander powder. The sensory 
Table II. Changes of water activity of coriander powder in heat sealable laminated aluminium film, HDPE film and PP film

\begin{tabular}{c|c|c|c}
\hline \multirow{2}{*}{$\begin{array}{c}\text { Period } \\
\text { (month) }\end{array}$} & \multicolumn{3}{|c}{ Water activity $\left(\mathrm{A}_{\mathrm{w}}\right.$ ) Temp. 24.9 $9^{\mathrm{O}}$} \\
\cline { 2 - 4 } & $\begin{array}{c}\text { Heat sealable laminated } \\
\text { aluminium film }\end{array}$ & $\begin{array}{c}\text { High density polyethylene } \\
\text { (HDPE) }\end{array}$ & $\begin{array}{c}\text { Poly propylene film } \\
\text { (PP) }\end{array}$ \\
\hline 0 & 0.579 & 0.265 & 0.265 \\
2 & 0.475 & 0.506 & 0.576 \\
4 & 0.491 & 0.543 & 0.583 \\
6 & 0.543 & 0.538 & 0.540 \\
8 & 0.560 & 0.574 & 0.582 \\
10 & 0.610 & 0.621 & 0.645 \\
12 & 0.575 & 0.648 & 0.661 \\
Reference sample & 0.418 & 0.422 & 0.543 \\
at $+5^{\mathrm{O}} \mathrm{C}$ & & & \\
\hline
\end{tabular}

Table III. Changes of weight of packaging bags and moisture of coriander powder in heat sealable laminated aluminium film, HDPE film and PP film

\begin{tabular}{c|c|c|c|c|c|c}
\hline $\begin{array}{c}\text { Period } \\
\text { (month) }\end{array}$ & \multicolumn{2}{|l|}{$\begin{array}{l}\text { Heat sealable laminated } \\
\text { aluminium film }\end{array}$} & \multicolumn{2}{|c|}{$\begin{array}{c}\text { High density } \\
\text { polyethylene (HDPE) }\end{array}$} & \multicolumn{2}{c}{$\begin{array}{c}\text { Poly propylene film } \\
\text { (PP) }\end{array}$} \\
\hline & $\begin{array}{c}\text { Initial wt. } \\
\text { of bag (g) }\end{array}$ & $\begin{array}{c}\text { Moisture } \\
(\%)\end{array}$ & $\begin{array}{l}\text { Initial wt. } \\
\text { of bag (g) }\end{array}$ & $\begin{array}{c}\text { Moisture } \\
(\%)\end{array}$ & $\begin{array}{r}\text { Initial wt. } \\
\text { of bag (g) }\end{array}$ & $\begin{array}{c}\text { Moisture } \\
(\%)\end{array}$ \\
\hline 0 & 57.00 & 3.95 & 57.00 & 3.95 & 54.00 & 3.95 \\
2 & 58.00 & 5.78 & 58.00 & 5.78 & 56.00 & 7.55 \\
4 & 59.00 & 6.77 & 59.00 & 6.77 & 56.00 & 7.52 \\
6 & 59.00 & 7.02 & 59.00 & 7.02 & 60.00 & 7.59 \\
8 & 59.00 & 7.12 & 59.00 & 7.12 & 56.00 & 7.28 \\
10 & 60.00 & 7.68 & 60.00 & 7.68 & 58.00 & 8.86 \\
12 & 60.00 & 8.64 & 60.00 & 8.64 & 58.00 & 8.80 \\
\hline Reference sample & 58.00 & 4.32 & N.D & 5.21 & N.D & 6.70 \\
at $+5^{\mathrm{O}}$ C & & & & & & \\
\hline
\end{tabular}

qualities were not same in all the packaging materials. The flavour remained unchanged upto two months in PP and six months in HDPE but quite strong flavour upto 12th months in heat sealable laminated aluminium film. There were no big lumps of coriander powder at ambient condition in the flexible packets. The PP \& HDPE packaging materials are polymer products and pollute the environment. Between PP \& HDPE, the 
Table IV. Changes of total ash acid insoluble ash of coriander powder in hear sealable laminated aluminium film, HDPE film and PP film

\begin{tabular}{c|c|c|c|c|c|c}
\hline $\begin{array}{c}\text { Period } \\
\text { (month) }\end{array}$ & \multicolumn{2}{|c|}{$\begin{array}{c}\text { Heat sealable laminated } \\
\text { aluminium film }\end{array}$} & \multicolumn{2}{c|}{$\begin{array}{c}\text { High density } \\
\text { polyethylene (HDPE) }\end{array}$} & \multicolumn{2}{|c}{$\begin{array}{c}\text { Poly propylene film } \\
\text { (PP) }\end{array}$} \\
\hline & $\begin{array}{c}\text { Total ash } \\
(\%)\end{array}$ & $\begin{array}{c}\text { Acid insoluble } \\
\text { ash (\%) }\end{array}$ & $\begin{array}{c}\text { Total ash } \\
(\%)\end{array}$ & $\begin{array}{c}\text { Acid insoluble } \\
\text { ash (\%) }\end{array}$ & $\begin{array}{c}\text { Total ash } \\
\text { (\%) }\end{array}$ & $\begin{array}{c}\text { Acid insoluble } \\
\text { ash (\%) }\end{array}$ \\
\hline 0 & 5.88 & 0.19 & 5.97 & 0.79 & 5.97 & 0.79 \\
2 & 5.50 & 0.14 & 5.82 & 0.69 & 5.82 & 0.73 \\
4 & 6.55 & 0.08 & 5.89 & 0.12 & 5.78 & 0.62 \\
6 & 5.86 & 0.26 & 5.67 & 0.72 & 5.66 & 0.81 \\
8 & 5.49 & 0.07 & 5.68 & 0.58 & 5.61 & 0.57 \\
10 & 5.70 & 0.10 & 5.57 & 0.55 & 5.52 & 0.62 \\
12 & 5.68 & 0.12 & 5.59 & 0.72 & 5.53 & 0.62 \\
\hline Reference sample & 5.51 & 0.14 & 5.64 & 0.65 & 5.59 & 0.60 \\
at + 5 ${ }^{\circ}$ C & & & & & & \\
\hline
\end{tabular}

thickness of PP (35 micron) was less than HDPE (50 micron) and hence PP was more porous.

As a result during drying season water vapour came out from the PP bag showing less weight in comparison to HDPE. But

Table V. Sensory quality of coriander powder in heat sealable laminated aluminium film

\begin{tabular}{c|c|c|c|c}
\hline $\begin{array}{c}\text { Period } \\
\text { (month) }\end{array}$ & Texture & Colour & Flavour & Appearance \\
\hline 0 & Good & Good & Strong & Good \\
2 & Good & Good & Strong & Good \\
4 & Good & Good & Strong & Good \\
6 & Good & Good & Strong & Good \\
8 & Good & Good & Strong & Good \\
10 & Good & Good & Strong & Good \\
12 & Good & Good & Strong & Good \\
\hline
\end{tabular}

aluminium film is not a polymer and is environment friendly, compatible with most food and resistant to most chemicals and it is impervious to grease, vapour, moisture and ultra violet light (Hemant, 1992). Actually aluminium foil is a thin film of aluminium alloy having $99 \%$ pure aluminium with other

Table VI. Sensory quality of coriander powder in HDPE film

\begin{tabular}{c|c|c|c|c}
\hline $\begin{array}{c}\text { Period } \\
\text { (month) }\end{array}$ & Texture & Colour & Flavour & Appearance \\
\hline 0 & Good & Good & Strong & Good \\
2 & Good & Good & Strong & Good \\
4 & Good & Good & Strong & Good \\
6 & Good & Light & Strong & Good \\
8 & Good & Light & Less Strong & Good \\
10 & Good & Light & Less Strong & Small lump \\
12 & Good & Light & Less Strong & Small lump \\
\hline
\end{tabular}


Table VII. Sensory quality of coriander powder in PP film

\begin{tabular}{c|c|c|c|c}
\hline $\begin{array}{c}\text { Period } \\
\text { (month) }\end{array}$ & Texture & Colour & Flavour & Appearance \\
\hline 0 & Good & Good & Strong & Good \\
2 & Good & Good & Strong & Good \\
4 & Good & Light & Less Strong & Good \\
6 & Good & Light & Less Strong & Small lump \\
8 & Good & Light & Less Strong & Small lump \\
10 & Good & Light & Less Strong & Small lump \\
12 & Good & Light & Less Strong & Small lump \\
\hline
\end{tabular}

trace amount of metals (Robertson, 1992). When rolled, this thin aluminium acts as a very good barrier to $\mathrm{O}_{2}$ and water vapour transmission but is fragile. Strength is added by laminating the foil with paper or plastic to produce a high quality package (Potter, et. al., 1996).

\section{Conclusion}

Among the three packaging materials the shelf life of coriander powder is found as the best in heat sealable laminated aluminium film. It may be concluded from this study that changes of water activity to higher value deteriorate the sensory qualities of coriander powder. So for long time storage at ambient condition, heat sealable laminated aluminium film packet is suitable for coriander powder.

\section{References}

Ahmed, K.M Udvid, Pashu-Pakhi O Matsha Sampad (1984) (Plant, Animal-Bird and Fish Wealth), 4th Ed. Published by Sarbajanin Granthalay, New Market, Dhaka-1205. 235.

Bangladesh Standard Specification for Coriander Powder, BDS 1084 : 1984. Bangladesh
Standards and Testing Insti-tution, 116/A Tejgaon Industrial Area, Dhaka-1208. Bangladesh, (May-1988), pp 4.

Basu et.el. (1947) Journal of Indian Chemical Society 24: 358.

Gilbert, S.T. (1986) New concepts on water activity and storage stability. In: The shelf life of Foods and Beverages. Charalambors. G (Ed) Elseneir Science Publishers B.V. Amsterdam. 303-334.

Hemant U. B. (1992) Packaging India, Feb-Mar, 24: 6, 15.

Potter, N.N. Hotchkiss, J. H. Food Science, Fifth Edition, First Indian Edition: (1996) Published by S.K Jam for CBS Publishers \& Distributors. 4596/lA, 11 Daryaganj, New Delhi - 110002 (India), 489.

Ranganna, S. (1991) Hand book of Analysis and Quality Control for Fruit and Vegetable Products, Edition, 488.

Robertson, G L. (1992) Food Packagmg, Principles and Practice, Published by Marcel Dekker, Inc. 270, Madison Avenue, New York, New York, 10016. pp 183.

Swaminathan, M. Food Science, Chemistry and Experimental Foods, Second Enlarged Edition, The Bangalore Printing \& Publishing Co, Ltd. pp 283.

Wealth of India. (1950) Council of Scientific and Industrial Research, New Delhi, India. 2: pp 349.

Received : April 13, 2006;

Accepted : February 11, 2007 